\title{
Serum Levels of Interleukin 17 in Patients with Human Papilloma Virus Infection
} N.W.Mikhael ${ }^{1}$, A.M.Hamed ${ }^{1}$,A.A.El-Fallah ${ }^{2}$ and G.A.Attya ${ }^{1}$

${ }^{1}$ Dermatology, Venereology,Andrology, Dept., Faculty of Medicine, Benha Univ., Benha, Egypt

${ }^{2}$ Clinical and Chemical Pathology, Dept., Faculty of Medicine, Benha Univ., Benha, Egypt

E-Mail:ghada@gmail.com

\begin{abstract}
Warts (verrucas) are an extremely common, benign, and usually self-limited skin disease. Infection of epidermal cells with the human papillomavirus (HPV) results in cell proliferation and a thickened, warty papule on the skin. The aim of this study was to evaluate serum levels of Interleukin 17 in patients with verrucas,correlate their levels with different demographic and clinical data. Method: This present study included: patient group(1) included 30 verruca patients. In addition,15apparently healthy, age and sex matched individuals included as a control group (Group 2). All patients were selected from outpatient clinic of Dermatology ans Andrology department of Benha University Hospital from Jan 2020 t0 July 2020. Informed consents were obtained from all participants. The study was approved by the local ethics committee on research involving human subjects, Faculty of Medicine , Benha University. Results and conclusion: it is concluded that IL 17 levels are lower in verruca patients than controls.
\end{abstract}

Keywords: Interleukin 17, Papilloma, Virus.

\section{Introduction}

Warts (verrucas) are an extremely common, benign, and usually self-limited skin disease. Infection of epidermal cells with the human papillomavirus (HPV) results in cell proliferation and a thickened, warty papule on the skin. There are over 100 different types of HPV. More than 40 different types of HPV can infect the skin covering the sex organs, cervix and opening of the anus [1].

Interleukin 17 (IL-17) is a pro-inflammatory cytokine involved in the control of many different disorders that include autoimmune, oncogenic, and many infectious diseases. T cells that produce IL-17 arise as a specific population of CD4-positive $\mathrm{T}$ cells, which are called T helper 17 (Th17) cells that are distinct from the classic Th1 and Th2 cells [2]

The aim of this study is to evaluate the serum level of Interleukin 17 in patients with verrucas, and to correlate their levels with different demographic and clinical data.

\section{Patients and methods}

This prospective case-control study, included 30 patients suffering from HPV infection, in addition, 15 apparently healthy, age and sex matched individuals as a control group. All patients were selected from the Outpatient Clinic of Dermatology and Andrology Department of Benha University Hospitals .

This study was approved by the local ethics committee on research involving human subjects of Benha Faculty of Medicine. A written informed consent was obtained from each patient or each healthy volunteer in the control group before sample collection.

\subsection{Inclusions criteria}

All patients were enrolled in the study had clinically confirmed HPV infection.

\subsection{Exclusion criteria}

- Patients suffering from any systemic disease (tumors, infections and autoimmune)
- Patients with any skin disease other than HPV infection.

All groups were subjected to the full history taking, complete clinical examination and laboratory investigations including: Determination of the serum levels of Interleukin 17 using ELISA technique.

\subsection{Statistical Analysis}

The collected data were coded, processed and analyzed using the SPSS (Statistical Package for Social Sciences) version 22 for Windows ${ }^{\circledR}$ (IBM SPSS Inc, Chicago, IL, USA). Qualitative data were represented as frequencies and relative percentages. Chi square test $(\chi 2)$ to calculate difference between two or more groups of qualitative variables. Quantitative data were expressed as mean \pm SD (Standard deviation). Independent samples ttest was used to compare between two independent groups of normally distributed variables (parametric data). Receiver operator characteristic (ROC) curve was tested to calculate the diagnostic ability of quantitative variable in prediction of categorical outcome. $\mathrm{P}$ value < 0.05 was considered significant.

\section{Results}

The present study included 30 patients with warts and 15 healthy control subjects. The mean age in patients' group was $30 \pm 3.2$ years. They were 15 males $(50 \%)$ and 15 females $(50 \%)$, while the mean age in the control group was $29.7 \pm 3.5$ years, they were 10 males $(66.6 \%)$ and 5 females $(33.4 \%)$. There was insignificant difference between patients and controls in age and gender ( $p>0.05$ for each)

The median disease duration was 6.8 months, it ranged from 3 to 12 months. The median number of warts per case was 3 , with a range between 2 to 8 warts. Many sites were affected, most common affected sites were hand $(60 \%)$, followed by foot $(25 \%)$, face $(9 \%)$, and genital $(6 \%)$ 
There was non statistically significant decrease in serum level of IL17 in patients when compared to control group. (385.19 vs 401.5 respectively).
IL17 serum level showed non statistically significant correlation with disease duration, number of warts, age and BMI of patients Table (1).

Table (1) Correlations between serum level of IL17 with age, BMI, disease duration and number of warts in cases group.

\begin{tabular}{lccc}
\hline & \multicolumn{2}{c}{ LL17 } \\
\cline { 2 - 4 } & ps & 0.084 \\
Age & -0.301 & 0.06 \\
BMI & -0.157 & 0.11 \\
Number & -0.605 & 0.46 \\
\hline
\end{tabular}

rs, correlation coefficient.

\section{Discussion}

Results of the present study showed that, cases group showed non statistically significant lower IL17 levels when compared to control group.

This is similar to the results of Metwally et al. [3] who revealed a significant decrease in serum IL-17 levels in wart patients.

Results of the present study revealed a non significant correlation between IL17 serum level and both disease duration and number of warts.

These results agreed with Ghanem et al. [4] who showed insignificant correlation between serum IL-17 levels of studied patients and disease duration and the number of wart $(\mathrm{P}>.05)$

The present study revealed an insignificant correlation between IL 17 seum level and both age and BMI of patients.

Our results with agreement with another researchers $[5,6,7]$, who showed that there is no statistically significant correlation between IL-17 serum level and both age and BMI of patients.

\section{Conclusion}

From the results of present study, it is concluded that IL 17 levels are lower in verruca patients than controls , IL17 serum levels could play a role in the pathogenesis of warts, however its role is still a matter of debate and still in need for further research

\section{References}

[1] L. Khondker, M. O. R. Shah, and M. S. S. I. Khan, "Verruca: need to know about human papilloma virus (HPV) infection," J. Bangladesh Coll. Physicians Surg., vol. 30, pp. 151-158, 2012.

[2] K. B. Nguyen. Coordinated and distinct roles for IFN- $\alpha \beta$, IL-12, and IL-15 regulation of NK cell responses to viral infection," J. Immunol., vol. 169, pp. 4279-4287, 2002.

[3] C.Albanesi, C.Scarponi, A. Cavani, M. Federici, F. Nasorri, and G. Girolomoni, "Interleukin-17 is produced by both Th1 and Th2 lymphocytes, and modulates interferon- $\gamma$-and interleukin-4-induced activation of human keratinocytes," J. Invest. Dermatol., vol. 115, pp. 81-87, 2000.

[4] A.H.Ghanem, A.M. Esawy, N. A. Khalifa, and H. M. Kamal, "Evaluation of serum interleukin 17 and zinc levels in recalcitrant viral wart," J. Cosmet. Dermatol., vol. 19, pp. 954-959, 2020.

[5] P. Bagri, V. C. Anipindi, P. V Nguyen, D. Vitali, M. R. Stämpfli, and C. Kaushic, "Novel role for interleukin-17 in enhancing type 1 helper $\mathrm{T}$ cell immunity in the female genital tract following mucosal herpes simplex virus 2 vaccination," J. Virol., vol. 91, pp. 203-212, 2017.

[6] I.Pantano . Secukinumab efficacy in patients with PsA is not dependent on patients' body mass index," Ann. Rheum. Dis., vol. 5, pp. 435, 2020.

[7] X. M. Wang, "Advances and issues in flow cytometric detection of immunophenotypic changes and genomic rearrangements in acute pediatric leukemia," Transl. Pediatr., vol. 3, p. 149, 2014. 